\title{
Covid-19 Vaccination as Part of The Basic Right to Health, Should it be Mandatory During The Covid-19 Pandemic
}

\author{
Lefri Mikhael \\ Faculty of Law Sebelas Maret University, Surakarta, Indonesia \\ *E-mail:lefrimikha@student.uns.ac.id
}

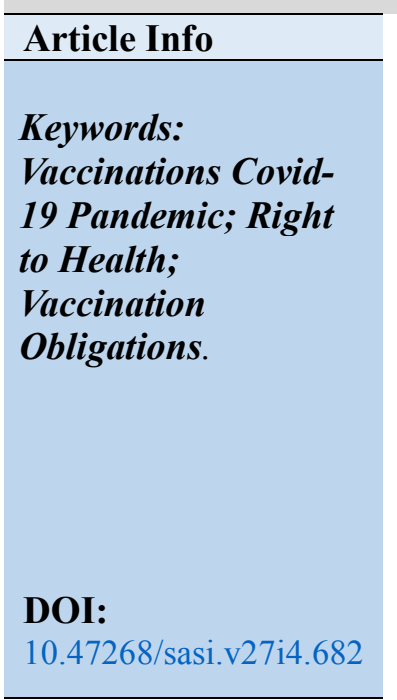

Abstract
The 2019 Coronavirus disease virus that shocked the world at the beginning
of 2020 as a pandemic had consequences for several sectors of life,
especially human health. Health as a fundamental human right that is
owned by every human being needs to be considered during the Pandemic.
Various efforts have been made by the Government to deal with this
situation, one of them is the Covid-19 vaccination. Then, the question is
whether the vaccination is optional or mandatory. The research carried out
is a normative juridical research with a conceptual approach and a
statutory approach related to the Covid-19 vaccination policy and the
collection of legal materials obtained through a literature study. In
summary, this article explains that the Covid-19 vaccination is part of the
fulfillment of the right to health during the Pandemic and it can be said as
an obligation for those who are prioritized as vaccine recipients, with the
main reason of achieving public health.

\section{A. INTRODUCTION}

The 2019-Coronavirus disease virus (hereinafter referred to as Covid-19) took the storm to world at the beginning of 2020. This situation is declared by the World Health Organization as a pandemic that primarily affects the health sector, with various other sectors as additional damage. As a result because this virus, it is recorded that at least 4,687,006 people have died as of September 20, 2021 ${ }^{1}$. Corona Virus Disease-19 (COVID-19) has a significant impact on all aspects of human life in the world, especially in Indonesia which is very large in area and has a large population (around 267 million people) with different kinds of professions ${ }^{2}$. As a health crisis, the Covid-19 pandemic directly affects the right to health which is recognized in various international human rights law instruments so that such a situation can be considered as a form of failure to fulfill human rights to achieve proper physical and mental health standards as stated in the International Covenant on Economic, Social and Cultural Rights.

The Covid-19 pandemic on global economic developments has an influence not only on

1 World Health Organization, 2021, “Confirmed Case of Covid-19 Globally”, Sept 20. https://covid19.who.int/.

${ }^{2}$ Kunarso, K., \& Sumaryanto, A. D. (2020). Eksistensi Perjanjian Ditengah Pandemi Covid-19. Batulis Civil Law Review, 1(1), 33-46.

423|S ASI Volume 27 Issue 4, October - December 2021 
the world of economy and investment, but also correlates with aspects of legal development ${ }^{3}$. A lot of efforts have been made by the Government in various countries, both emergency law regulations and measurable policies to fight the spread of Covid-19, such as regional quarantine, travel bans or travel restrictions, until total lockdowns. In addition, the Government has also prioritized health service priorities related to Covid-19, such as prioritizing healing for patients affected by Covid-19, promoting testing and tracing of Covid-19 cases, which leads to negative impacts by placing access to non-Covid10 pasients health services as secondary priority.

Such challenges gave a new idea of the need for effective treatment methods, or at least the use of safe, effective, and efficient vaccines through vaccination activities. Vaccination is the injection of vaccines (antigens) that can stimulate the formation of immunity (antibodies) of the immune system in the body ${ }^{4}$. Vaccines can be considered as a temporary solution aimed at establishing a communal self-immunity or known as "herd immunity", which is defined as immunization of a large part of the population to control an epidemic (or global pandemic) and to prevent a larger outbreak from occurring ${ }^{5}$.

The government's efforts to maintain public safety and maintain economic stability, in the spread of COVID-196. Indonesia itself has carried out mass vaccinations in various regions starting from mid-January 2021 until now. The implementation of this policy is based on Presidential Regulation No. 14 of 2021 on Amendment of Presidential Regulation No. 99 of 2020 on the Procurement of Vaccines and the Implementation of Vaccinations in the Context of Combating the Coronavirus Disease 2019 (Covid-19) pandemic. At the level of regulation and implementation, there is one fundamental problem, namely the existence of an article clause that states that vaccination is an obligation for those who are listed as the target of recipients, amid public fear and distrust of the safety and efficacy of the vaccine. So this raises a problem, which can the Covid-19 vaccination during this Pandemic, which was originally considered as a human right, be transformed into an obligation.

This research is a normative juridical research by reviewing the vaccination policy and analyzing the relevant laws and regulations. The approach taken is a conceptual approach and a statutory approach related to the Covid-19 vaccination policy. The legal sources used consist of primary legal sources, starting from international conventions, the Constitution, laws, to Presidential Regulations and related Minister of Health Regulations. Secondary legal materials are in the form of legal book, scientific journals, and papers, along with relevant internet sources. The collection of primary legal materials and secondary legal materials was obtained through literature study.

\section{B. RESULTS AND DISCUSSION}

\section{Vaccines As Part of Human Rights to Health}

According to the literature, there are 2 terms related to human rights in the health sector, namely right to health and right to attainable standard to health ${ }^{7}$. The right to standards of health plays an important role in the effective handling of the pandemic ${ }^{8}$. Recognition of human

3 Saija, R., \& Sudiarawan, K. A. (2021). Perlindungan Hukum Bagi Perusahaan Debitur Pailit dalam Menghadapi Pandemi Covid 19. Batulis Civil Law Review, 2(1), 66-77.

4 Bali Provincial Health Office, 2021, "Yuk, Kenali lebih jauh Vaksinasi Covid-19", Sept 19. https://www.diskes.baliprov.go.id/yuk-kenali-lebih-jauh-vaksinasi-covid-19/.

5 Fontanet, A., \& Cauchemez, S. (2020). COVID-19 herd immunity: where are we?. Nature Reviews Immunology, 20(10), 583-584.

6 Taun, T., \& Nugraha, A. (2020). Penerapan Hukum dalam Pemutusan Hubungan Kerja dan Kebijakan Bank Terhadap Debitur yang Terdampak Pandemi Covid-19. Batulis Civil Law Review, 1(1), 24-32.

7 Hidayat, R. A. (2017). Hak Atas derajat pelayanan kesehatan yang optimal. Syariah: Jurnal Hukum dan Pemikiran, 16(2), 127-134.

${ }^{8}$ Forman, L., \& Kohler, J. C. (2020). Global health and human rights in the time of COVID-19: Response, restrictions, and legitimacy. Journal of Human Rights, 19(5), 547-556.

424|SASI Volume 27 Issue 4, October - December 2021 
rights to health is recognized in multi-level settings. International legal instruments that recognize human rights to health include Article 25 paragraph (1) part A of the Universal Declaration of Human Rights which stated, "Everyone has the right to a standard of living adequate for the health and well-being of himself and of his family, including food, clothing, housing and medical care and necessary social services ..." 9 , furthermore in Article 12 paragraph (1) ICESCR stated, "The States Parties to the present Covenant recognize the right of everyone to the enjoyment of the highest attainable standard of physical and mental health" 10 . In the context of child health, it is recognized in Article 24 paragraph (1) of the Convention on the Rights of the Child stated, "States Parties recognize the right of the child to the enjoyment of the highest attainable standard of health and to facilities for the treatment of illness and rehabilitation of health. States Parties shall strive to ensure that no child is deprived of his or her right of access to such health care services."11.

At the national level, the fundamental acknowledgment is mentioned at Article $28 \mathrm{H}$ paragraph (1) of the Constitution 1945 which stated "Everyone has the right to live in physical and spiritual prosperity, to have a place to live, and to have a good and healthy environment and have the right to obtain health services." ${ }^{12}$, which was subsequently revealed in Law Number 39 of 1999 on Human Rights as a form of crystallization of human rights recognitions, Article 9 stated "(1) Everyone has the right to live, maintain life and improve their standard of living. (2) Everyone has the right to live peacefully, safely, peacefully, happily, physically and mentally." ${ }^{3}$. The last recognition in Law Number 36 of 2009 on Health as a lex specialias, Article 4 mentioned "Everyone has the right to health" and Article 5 paragraph (1) "Everyone has the same right in obtaining access to resources in the health sector."14.

The various recognitions above show clearly that health rights is placed as part of human rights which has a strategic position in order to be able to achieve other aspects of human rights ${ }^{15}$. Furthermore, the recognition of these rights is balanced with the recognition of obligations for the state to fulfill them through take steps, individually and through international assistance and co-operation, especially economic and technical, to the maximum of its available resources, vith a view to achieving progressively the full realization of the rights recognized in the present as stated in Article 2 paragraph (1) ICESCR. This obligation also applies during this pandemic, where through UN Committee on Economic, Social and Cultural Rights tated his statement on April 17, 2020, that is still respecting and protecting the inherent dignity of all people $^{16}$. The constitutional mandate in Article 28I paragraph (4) of the 1945 Constitution places the protection, promotion, enforcement and fulfillment of human rights into the responsibility of the state ${ }^{17}$.

The implementation of this responsibility is through the obligation to provide essential health services related to Covid-19 for free, including providing treatment or at least a vaccine that is effective in protecting human health as a form of preventing the negative impacts of Covid-19 in order to produce immunity and form a healthy person. Implementation of mass vaccination according to the regulations of Presidential Regulation Number 14 of 2021 on Amendment of Presidential Regulation Number 99 of 2020 on Vaccine Procurement and

9 Article 25 para. (1)A of the Universal Declaration of Human Rights.

10 Article 12 para. (1) of the International Covenant on Economic, Social and Cultural Rights.

11 Article 24 para. (1) of the Convention on the Rights of the Child.

12 Article 28H para. (1) of the 1945 Constitution of Republic Indonesia.

13 Article 9 of Law Number 39 of 1999 on Human Rights..

14 Article 4 and Article 5 of Law Number 36 of 2009 on Health.

15 Kurniawan, M. B. (2021). Politik Hukum Pemerintah dalam Penanganan Pandemi Covid-19 Ditinjau dari Perspektif Hak Asasi atas Kesehatan. Jurnal HAM, 12(1), 37-56.

${ }^{16}$ UN Committee On Economic, Social And Cultural Rights, 2020, "Statement on the coronavirus disease (COVID-19) pandemic and economic, social and cultural rights” UN Doc. E/C.12/2020/1 (See Para. 12, p3), Geneva: United Nations.

17 Article 28I para. (4) of the 1945 Constitution of Republic Indonesia.

425|SASI Volume 27 Issue 4, October - December 2021 
Vaccination Implementation in the Context of Combating the 2019 Coronavirus Disease (Covid-19) pandemic..

The realization of mass vaccination has been carried out since January 13, 2021, as the beginning of a 4-stage plan, which are: The first stage: intended for health workers, assistant health workers, support personnel and for students who are undergoing medical professional education who work in Health Service Facilities; The second stage: intended for public service officers, namely the Indonesian National Armed Forces/State Police of the Republic of Indonesia, law enforcement officers, and other public service officers including officers at airports/ports/stations/terminals. Then, for workers in the banking sector, state electricity companies, and regional drinking water companies, as well as other officers who are directly involved in providing services to the community. In addition, in the second stage, the recipients of the COVID-19 vaccine also include the elderly age group or aged 60 years or older; Third stage: for vulnerable people from geospatial, social, and economic aspects; Fourth stage: intended for the community and other economic actors with a cluster approach according to the availability of vaccines ${ }^{18}$.

These stages are in accordance with the priority targets that characterize the principle of non-discrimination as stated in the Minister of Health Regulation Number 84 of 2020 on Implementation of Vaccination in the Context of Combating the Corona Virus Disease 2019 (COVID-19) Pandemic, Article 8 paragraph (3) mentions the priority group of recipients consisting of:

a) Health workers, assistant health workers, supporting staff working in Health Service Facilities, the Indonesian National Armed Forces, the Indonesian National Police, law enforcement officers, and other public service officers;

b) Community/religious leaders, strategic economic actors, sub-district officials, village officials, and neighborhood units/rukun residents;

c) Teachers/educators from kindergarten, elementary school, junior high school, senior high school, or equivalent, and universities;

d) Apparatus of ministries/agencies, apparatus of local government organizations, and members of the legislature;

e) Vulnerable people from geospatial, social, and economic aspects;

f) Society and other economic actors ${ }^{19}$.

In addition to being responsible for providing access to vaccinations for the public, the Government is also obliged to supervise the implementation of the vaccination and the effects arising from the injection of vaccines in order to ensure accountability and safety. The government regulates state accountability in the form of compensation for cases of severe postvaccination impacts, such as disability or death with the appropriate mechanism Article 15B Presidential Regulation Number 14 of 2021.

\section{Covid-19 Vaccination at the Crossroads of Rights or Obligations}

Since the promotion of vaccination during the Covid-19 pandemic, the discourse on the position of vaccination for the community as a right or obligation has resurfaced. Broadly speaking, it is a conflict between common safety or the principle of individual freedom.. Article 13A Paragraph (2) Presidential Regulation Number 14 of 2021 stated, "every person who has been designated as the target recipient of the COVID-19 Vaccine based on the data collection as referred to in paragraph (1) must take part in the COVID-19 Vaccination" ${ }^{20}$. In fact, DKI

18 Ayunda, R., Kosasih, V., \& Disemadi, H. S. (2021). Perlindungan Hukum Bagi Masyarakat Terhadap Efek Samping Pasca Pelaksanaan Vaksinasi Covid-19 Di Indonesia. NUSANTARA: Jurnal Ilmu Pengetahuan Sosial, 8(3), 194-206.

19 Article 8 para. (3) of Minister of Health Regulation Number 84 of 2020 on Implementation of Vaccination in the Context of Combating the Corona Virus Disease 2019 (COVID-19) Pandemic.

20 Article 13A para. (2) of Presidential Regulation Number 14 of 2021 on Amendment of Presidential

426|S ASI Volume 27 Issue 4, October - December 2021 
Jakarta Province through Regional Regulation Number 2 of 2020 threatens those who deliberately refuse the Covid-19 vaccination can be fined a maximum of Rp5.000.000 ${ }^{21}$.

In the national legal order, the argument for vaccination as a right is based on Article 5 paragraph (3) of Law Number 36 of 2009 on Health ${ }^{22}$ states that, "Everyone has the right to independently and responsibly determine the health services needed for himself.". While the argument for mandatory vaccination is in Article 14 paragraph (1) of Law Number 4 of 1984 on Infectious Disease Outbreak states that "Whoever deliberately obstructs the implementation of epidemic control as regulated in this law, is threatened with imprisonment for a maximum of 1 (one) year and/or a maximum fine of Rp. 1,000,000."23. Another obligation is in Article 93 of Law Number 6 of 2018 on Health Quarantine which stated, "everyone who does not comply with the implementation of Health Quarantine as referred to in Article 9 paragraph (1) and/or obstructs the implementation of Health Quarantine causing a Public Health Emergency, shall be sentenced to a maximum imprisonment of 1 (one) year and/or a maximum fine of $\mathrm{Rp}$. 100,000.00.." 24 with Article 9 stated "(1) Everyone is obliged to comply with the implementation of Health Quarantine. (2) Everyone is obliged to participate in the implementation of Health Quarantine."25.

In comparison, the Supreme Court (Federal Supremo Tribunal, or STF) in Brazil, assessing that mandatory vaccination must meet several basic requirements, namely the existence of scientific evidence regarding the safety and efficacy of vaccines by national health institutions, free and universal access to vaccines must be available, while respecting human rights and fulfilling fairness and proportionality tests ${ }^{26}$. Another consideration was conveyed by WHO which stated that in making vaccine mandatory policies, it was necessary to pay attention to several ethical considerations, which are:

1) If it is considered important and proportional between the goals of public health and individual freedom, and needs to be legitimized by the national health authorities. If there are other steps to achieve the condition of herd immunity, then the obligation is considered unnecessary.

2) There is evidence that vaccines are safe, effective, and efficient.

3) The availability of adequate vaccines, free of charge for the required targets, and easy to obtain.

4) Supported by public trust.

5) There is transparency and accountability in the process of implementing vaccination $^{27}$.

In the end, what every individual needs to remember is that basically everyone is also obliged to respect the human rights of others, including being subject to restrictions set by law which are solely aimed at ensuring the recognition and respect for the rights and freedoms of others according to moral considerations, religious values, and common security. In addition, theoretically a country can be justified in limiting human rights that are classified as nonderogable rights during an emergency situation. Alexander Domrin classified emergencies as

Regulation Number 99 of 2020 on Vaccine Procurement and Vaccination Implementation in the Context of Combating the 2019 Coronavirus Disease (Covid-19) pandemic.

21 Article 30 Provincial Regulation of the Special Capital Region of Jakarta Number 2 of 2020 on Combating Coronavirus Disease-2019.

22 Article 5 para. (3) of Law Number 36 of 2009 on Health.

23 Article 14 para. (1) of Law Number 4 of 1984 on Infectious Disease Outbreak.

24 Article 93 of Law Number 6 of 2018 on Health Quarantine.

25 Article 9 of Law Number 6 of 2018 on Health Quarantine.

26 Wang, D. W. L., Moribe, G., \& Arruda, A. L. G. D. M. (2021). Is Mandatory Vaccination for COVID-19 Constitutional under Brazilian Law?. Health and Human Rights, 23(1), 163.

27 World Health Organization. (2021). COVID-19 and mandatory vaccination: ethical considerations and caveats: policy brief, 13 April 2021. In COVID-19 and mandatory vaccination: ethical considerations and caveats: policy brief, 13 April 2021. p.2-5.

427|SASI Volume 27 Issue 4, October - December 2021 
consisting of foreign invasions, treason, serious services carried out and public security, disasters, violations in the economy, major public disturbances, and monetary crises. ${ }^{28}$. These restrictions must be temporary, aimed at overcoming the crisis, and with the intention of returning them to their original condition, with major objectives, one of which is to protect public health, ${ }^{29}$ because of the adagium of Salus Populi Suprema Lex Esto (the safety of the people is the highest law).

\section{CONCLUSION}

The Covid-19 pandemic has had a major impact on various sectors of life, but the human health sector is the most affected. This emergency situation endangers the security and safety of the community so that it affects the fulfillment of the human right to health, as a fundamental human right. Various efforts have been made by countries to deal with the negative impacts of Covid-19, one of which is mass vaccination of their population in order to form herd immunity, as an effort to fulfill human rights to health during a pandemic, must respect the human rights of others. In addition, in an emergency, the State has the right to limit certain human rights with certain conditions of assessment. The main assessment in implementing the mandatory vaccination policy is as high as possible for the safety of the people, which of course also needs to be accompanied by other preventive and educational measures, as well as eliminating the existence of punishment for those who refuse as well as supervision and accountability of the Government in organizing the mass vaccination.

\section{REFERENCES}

\section{Journal}

[1] Ayunda, R., Kosasih, V., \& Disemadi, H. S. (2021). Perlindungan Hukum Bagi Masyarakat Terhadap Efek Samping Pasca Pelaksanaan Vaksinasi Covid-19 Di Indonesia. NUSANTARA: Jurnal Ilmu Pengetahuan Sosial, 8(3), 194-206.

[2] Fontanet, A., \& Cauchemez, S. (2020). COVID-19 herd immunity: where are we?. Nature Reviews Immunology, 20(10), 583-584.

[3] Forman, L., \& Kohler, J. C. (2020). Global health and human rights in the time of COVID19: Response, restrictions, and legitimacy. Journal of Human Rights, 19(5), 547-556.

[4] Hidayat, R. A. (2017). Hak Atas derajat pelayanan kesehatan yang optimal. Syariah: Jurnal Hukum dan Pemikiran, 16(2), 127-134.

[5] Kunarso, K., \& Sumaryanto, A. D. (2020). Eksistensi Perjanjian Ditengah Pandemi Covid19. Batulis Civil Law Review, 1(1), 33-46.

[6] Kurniawan, M. B. (2021). Politik Hukum Pemerintah dalam Penanganan Pandemi Covid19 Ditinjau dari Perspektif Hak Asasi atas Kesehatan. Jurnal HAM, 12(1), 37-56.

[7] Matompo, O. S. (2014). Pembatasan Terhadap Hak Asasi Manusia Dalam Prespektif Keadaan Darurat. Jurnal Media Hukum, 21(1), 16.

[8] Saija, R., \& Sudiarawan, K. A. (2021). Perlindungan Hukum Bagi Perusahaan Debitur Pailit dalam Menghadapi Pandemi Covid 19. Batulis Civil Law Review, 2(1), 66-77.

[9] Taun, T., \& Nugraha, A. (2020). Penerapan Hukum dalam Pemutusan Hubungan Kerja dan Kebijakan Bank Terhadap Debitur yang Terdampak Pandemi Covid-19. Batulis Civil Law Review, 1(1), 24-32.

[10] Wang, D. W. L., Moribe, G., \& Arruda, A. L. G. D. M. (2021). Is Mandatory Vaccination for COVID-19 Constitutional under Brazilian Law?. Health and Human Rights, 23(1), 163.

28 Alexander, D. N. (2006). The Limits of Russian Democratisation Emergency Powers and State of Emergency. London \& New York: Routledge.

29 Matompo, O. S. (2014). Pembatasan Terhadap Hak Asasi Manusia Dalam Prespektif Keadaan Darurat. Jurnal Media Hukum, 21(1), 16.

428|S A I Volume 27 Issue 4, October - December 2021 


\section{Books}

[11] Alexander, D. N. (2006). The Limits of Russian Democratisation Emergency Powers and State of Emergency. London \& New York: Routledge.

\section{Online/World Wide Web, Thesis etc}

[12] Bali Provincial Health Office, 2021, “Yuk, Kenali lebih jauh Vaksinasi Covid-19”, Sept 19. https://www.diskes.baliprov.go.id/yuk-kenali-lebih-jauh-vaksinasi-covid-19/.

[13]UN Committee On Economic, Social And Cultural Rights, 2020, "Statement on the coronavirus disease (COVID-19) pandemic and economic, social and cultural rights" UN Doc. E/C.12/2020/1 (See Para. 12, p3), Geneva: United Nations.

[14] World Health Organization, 2021, "Confirmed Case of Covid-19 Globally", Sept 20. https://covid19.who.int/.

[15] World Health Organization. (2021). COVID-19 and mandatory vaccination: ethical considerations and caveats: policy brief, 13 April 2021. In COVID-19 and mandatory vaccination: ethical considerations and caveats: policy brief, 13 April 2021. 